\title{
Nocardiopsis ganjiahuensis sp. nov., isolated from a soil from Ganjiahu, China
}

\author{
Xiumin Zhang, ${ }^{1,2}$ Li-Ping Zhang, ${ }^{2}$ Runlei Yang, ${ }^{2}$ Nan Shi, ${ }^{2}$ Zhitang Lu, ${ }^{2}$ \\ Wen Xin Chen, ${ }^{1}$ Cheng-Lin Jiang ${ }^{3}$ and Li-Hua $\mathrm{Xu}^{3}$
}

Correspondence

Li-Ping Zhang

zhlping@mail.hbu.edu.cn

\author{
${ }^{1}$ Key Laboratory of Agro-Microbial Resource and Application, Ministry of Agriculture/Department \\ of Microbiology, College of Biological Sciences, China Agricultural University, Beijing 100094, \\ PR China \\ ${ }^{2}$ Key Laboratory of Microbial Diversity Research and Application of Hebei Province, College of Life \\ Sciences, Hebei University, Baoding 071002, PR China \\ ${ }^{3}$ Yunnan Institute of Microbiology, Yunnan University, Kunming, Yunnan 650091, PR China
}

\begin{abstract}
An actinomycete, strain HBUM $20038^{\top}$, was isolated from soil from Ganjiahu Natural Reserve in Xinjiang Province, in north-western China, and then characterized using a polyphasic approach. $16 \mathrm{~S}$ rRNA gene sequence analysis confirmed that strain HBUM $20038^{\top}$ was a member of the genus Nocardiopsis, and the morphological and chemotaxonomic characteristics of the strain were also consistent with those of species of Nocardiopsis. DNA-DNA hybridization between the strain and related type strains gave relatedness values far below $70 \%$. These results, together with physiological characteristics, showed that strain HBUM $20038^{\top}$ represents a novel species within the genus Nocardiopsis, for which the name Nocardiopsis ganjiahuensis sp. nov. is

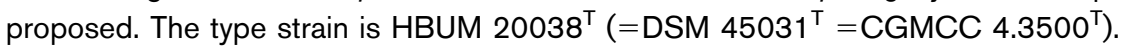

The genus Nocardiopsis was first described by Meyer (1976), and its members typically exhibit a branched substrate mycelium that fragments into rod-shaped and coccoid elements and abundant aerial hyphae that frequently form a zigzag morphology. The genus Nocardiopsis was subsequently shown to exhibit distinct chemotaxonomic characteristics: cell-wall chemotype III/C (meso-diaminopimelic acid and no diagnostic sugars in whole-cell hydrolysates; Lechevalier \& Lechevalier, 1970), phospholipid type PIII (phosphatidylcholine and phosphatidylmethylethanolamine as characteristic phospholipids; Lechevalier et al., 1977), menaquinone MK-10 with variable degrees of saturation in the side chain as the predominant isoprenoid quinone (Kroppenstedt, 1992), fatty acid type $3 \mathrm{~d}$ (containing iso-branched, anteisobranched and 10-methyl-branched chain fatty acids; Kroppenstedt, 1985) and DNA G + C contents between 64 and $71 \mathrm{~mol} \%$ (Grund \& Kroppenstedt, 1990). At the time of writing, 25 species and subspecies have validly published names (Euzéby, 2007). Most of them were isolated from habitats such as saline or alkaline soil and marine sediments. We isolated a novel strain, HBUM $20038^{\mathrm{T}}$, from an alkaline soil in western China. The aim of the study was to identify whether or not the strain represents a novel species within the genus Nocardiopsis by using phenotypic, genotypic and phylogenetic approaches.

The GenBank/EMBL/DDBJ accession number for the 16S rRNA gene sequence of HBUM $20038^{\top}$ is AY336513.
Strain HBUM $20038^{\mathrm{T}}$ was isolated on agar plates of DSMZ medium no. 852 (GYP medium, adjusted to $\mathrm{pH} 10$ with sterile saturated sodium carbonate solution after sterilization of the medium). Cultural characteristics of strain HBUM $20038^{\mathrm{T}}$ were observed by using 3-, 5-, 7- and 14day-old cultures grown on GYP agar at $28{ }^{\circ} \mathrm{C}$. The morphological properties and colours of aerial and substrate mycelium, as well as of diffusible pigments, were tested as described by Shirling \& Gottlieb (1966). Sporechain morphology and spore-surface ornamentation of 7day-old cultures grown on GYP agar were observed using an Olympus BH-2 light microscope and a KYKY-AMRAY100B scanning electron microscope. Strain HBUM $20038^{\mathrm{T}}$ formed powdery-surfaced colonies. The strain produced abundant grey-white aerial mycelium which divided into rod-shaped, smooth-surfaced and non-motile spores (0.3$0.5 \times 1.0-2.0 \mu \mathrm{m})$. It formed long, well-developed and branched substrate mycelium (Fig. 1). The substrate mycelium was light-yellowish. No diffusible pigments were produced on GYP agar medium. These morphological characteristics are consistent with those described for Nocardiopsis species (Kroppenstedt, 1992).

Biomass used for chemotaxonomic and molecular systematic studies was grown in shake flasks of GYP liquid medium for 4 days at $28{ }^{\circ} \mathrm{C}$. At maximum growth, the cultures were checked for purity and harvested by centrifugation and washed twice with distilled water. The isomeric form of diaminopimelic acid and diagnostic 


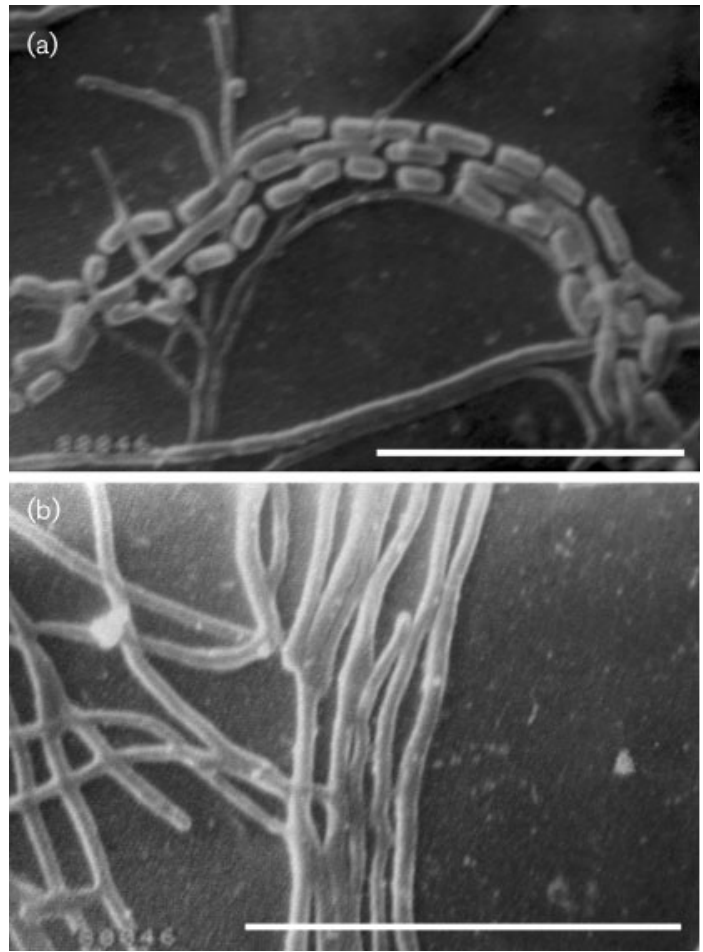

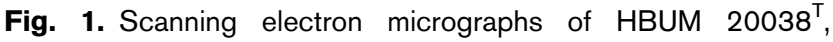
showing aerial mycelium divided into rod-shaped spores (a) and branched substrate mycelium (b). Bars, $10 \mu \mathrm{m}$.

sugars of whole-cell hydrolysates were determined following standard procedures described by Lechevalier \& Lechevalier (1980) and Hasegawa et al. (1983). Menaquinones were determined according to the methods of Collins (1985). Analysis of phospholipids was based on the procedure of Komagata \& Suzuki (1987). The cellular fatty acid composition was determined as described by Sasser (1990) using the Microbial Identification System (MIDI, Inc.). The chemical properties of the strain are consistent with those of the genus Nocardiopsis (Lechevalier \& Lechevalier, 1970). Cell walls of strain HBUM $20038^{\mathrm{T}}$ contained meso-diaminopimelic acid and no characteristic sugars were found in the strain. The diagnostic phospholipids contained quantities of diphosphatidylglycerol, phosphatidylcholine and phosphatidylmethylethanolamine (phospholipid type III; Lechevalier et al., 1977). The predominant menaquinones were MK$10\left(\mathrm{H}_{2}\right)$, MK-10 $\left(\mathrm{H}_{4}\right)$ and MK-10 $\left(\mathrm{H}_{6}\right)$. The major cellular fatty acids were iso- $\mathrm{C}_{16: 0}(41.03 \%), \mathrm{C}_{18: 1} \omega 9 c(14.73 \%)$ and tuberculostearic acid (10-methyl- $\left.\mathrm{C}_{18: 0}\right)$ (9.69\%). These chemical properties offer evidence that the strain should be classified in the genus Nocardiopsis (Collins \& Jones, 1981; Lechevalier \& Lechevalier, 1970; Lechevalier et al., 1977).

The physiological characteristics of the strain was tested using the methods described for the genus Nocardiopsis in Bergey's Manual of Determinative Bacteriology (Holt et al.,
1994) and the methods described by Evtushenko et al. (2000). Growth of strain HBUM $20038^{\mathrm{T}}$ on agar was observed at $\mathrm{pH}$ 8.5-13.0, while optimum growth occurred at $\mathrm{pH} 8.5-9.5$, and there was no growth at $\mathrm{pH}$ 7.0. The other results are listed in Table 1 or in the species description.

For 16S rRNA gene sequence analysis, determination of $\mathrm{G}+\mathrm{C}$ content and DNA-DNA hybridization, chromosomal DNA was extracted using the procedure described by Marmur (1961) and Kutchma et al. (1998). The $16 \mathrm{~S}$ rRNA gene was amplified by PCR with the universal primers 27f (Escherichia coli positions 8-27; 5'GAGTTTGATCCTGGCTCAG-3') and 1525r (E. coli positions 1525-1545; 5'-AGAAAGGAGGTGTACCAGCC-3') (Lane et al., 1985). The PCR conditions used were an initial denaturation at $95{ }^{\circ} \mathrm{C}$ for $10 \mathrm{~min}$, rapid cooling in an ice bath, addition of Taq DNA polymerase and instantaneous centrifugation followed by 30 cycles of denaturation at $95{ }^{\circ} \mathrm{C}$ for $30 \mathrm{~s}$, annealing at $54{ }^{\circ} \mathrm{C}$ for $30 \mathrm{~s}$ and extension at $72{ }^{\circ} \mathrm{C}$ for $90 \mathrm{~s}$ with a final extension at $72{ }^{\circ} \mathrm{C}$ for $5 \mathrm{~min}$. The resultant PCR products were purified and sequenced by Sangon Biological Engineering Co. Ltd (Shanghai, China). The $\mathrm{G}+\mathrm{C}$ content was determined by HPLC of deoxyribonucleosides by using the method of Mesbah et al. (1989). The initial reassociation-rate method (De Ley et al., 1970) was used for determining the percentage of DNADNA hybridization by using a spectrophotometer (model CE9500; Cecil Instruments) equipped with a programmable melting-temperature control unit.

The 16S rRNA gene sequence of the strain was aligned manually with corresponding sequences of representatives of the genus Nocardiopsis retrieved from the GenBank database using CLUSTAL_X version 1.64b (Thompson et al., 1997). Phylogenetic trees were inferred by using the neighbour-joining (Saitou \& Nei, 1987), FitchMargoliash (Fitch \& Margoliash, 1967) and maximumlikelihood (Felsenstein, 1981) methods. Evolutionary distance matrices for the neighbour-joining and FitchMargoliash methods were generated according to the algorithm of Jukes \& Cantor (1969) and the robustness of the tree topology of the neighbour-joining data was evaluated by bootstrap analysis (Felsenstein, 1993) based on 1000 resamplings using the SEQBOOT and CONSENSE options from the PHYLIP suite of programs.

The nearly complete $16 \mathrm{~S}$ rRNA gene sequence determined for strain HBUM $20038^{\mathrm{T}}$ (1434 nt) was aligned with corresponding sequences of representative reference strains of Nocardiopsis. It was evident from the phylogenetic tree (Fig. 2) that Nocardiopsis prasina DSM $43845^{\mathrm{T}}, \quad N$. metallicus $\mathrm{KBS6}^{\mathrm{T}}$, N. exhalans ES10.1 ${ }^{\mathrm{T}}, N$. alkaliphila DSM $44657^{\mathrm{T}}$, N. listeri DSM 40297 ${ }^{\mathrm{T}}, N$. alba DSM $43377^{\mathrm{T}}$, N. tropica VKM Ac- $1457^{\mathrm{T}}$, N. umidischolae 66/ $93^{\mathrm{T}}$, N. aegyptia DSM $44442^{\mathrm{T}}, N$. lucentensis DSM $44048^{\mathrm{T}}$ and strain HBUM $20038^{\mathrm{T}}$ formed a phylogenetic clade. Pairwise similarity values of 16S rRNA gene sequences $>97 \%$ were found between HBUM $20038^{\mathrm{T}}$ and related 
Table 1. Differential phenotypic characteristics of HBUM $20038^{\top}$ and closely related Nocardiopsis species

Strains: 1, strain HBUM $20038^{\mathrm{T}}$ (data from this study); 2, N. prasina DSM 43845 ${ }^{\mathrm{T}}$; 3, N. metallicus DSM $44598^{\mathrm{T}}$ (Schippers et al., 2002); 4 , N. exhalans DSM $44407^{\mathrm{T}}$ (Peltola et al., 2001); 5, N. alba DSM 43377 $; 7^{\mathrm{T}}$; 6, N. aegyptia DSM $44442^{\mathrm{T}}$ (Sabry et al., 2004); 7, N. lucentensis DSM 44048 ${ }^{\mathrm{T}}$; 8 , N. listeri DSM $40297^{\mathrm{T}}$. Unless indicated, data were taken from Evtushenko et al. (2000). +, Positive; -, negative; ND, no data.

\begin{tabular}{|c|c|c|c|c|c|c|c|c|}
\hline Characteristic & 1 & 2 & 3 & 4 & 5 & 6 & 7 & 8 \\
\hline Colour of aerial mycelium & Grey-white & White & White & White & Yellow or colourless & Beige to light yellow & White & Colourless \\
\hline \multicolumn{9}{|l|}{ Utilization of: } \\
\hline D-Xylose & + & + & + & + & - & + & - & + \\
\hline Sucrose & - & + & + & + & + & + & + & - \\
\hline L-Rhamnose & + & - & + & + & - & + & + & + \\
\hline Cellobiose & - & - & + & + & + & $\mathrm{ND}$ & + & - \\
\hline Glycerol & + & + & ND & $\mathrm{ND}$ & + & + & + & - \\
\hline myo-Inositol & + & - & ND & - & - & + & + & - \\
\hline \multicolumn{9}{|l|}{ Growth at/in: } \\
\hline $10{ }^{\circ} \mathrm{C}$ & + & - & + & + & - & + & + & + \\
\hline $28{ }^{\circ} \mathrm{C}$ & + & ND & + & + & ND & + & ND & $\mathrm{ND}$ \\
\hline
\end{tabular}

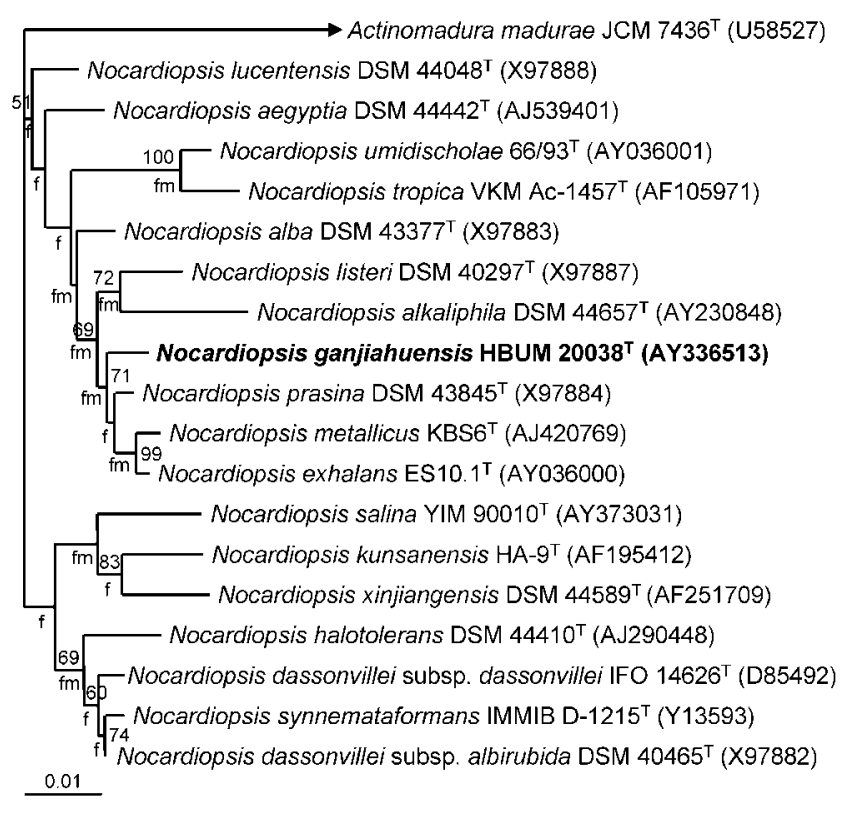

Fig. 2. Neighbour-joining tree (Saitou \& Nei, 1987), based on almost complete $16 \mathrm{~S}$ rRNA gene sequences, showing the relationship between strain HBUM $20038^{\top}$ and representatives of the genus Nocardiopsis. Actinomadura madurae JCM $7436^{\top}$ was used as the outgroup. Numbers at nodes indicate percentages of bootstrap support, based on a neighbour-joining analysis of 1000 resampled datasets; only values greater than $50 \%$ are given. ' $f$ ' represents clades recovered by the Fitch-Margoliash method; 'fm' represents clades recovered by both the FitchMargoliash and maximum-likelihood methods. Bar, 0.01 substitutions per nucleotide position. strains (Table 2). The DNA-DNA relatedness of strain HBUM $20038^{\mathrm{T}}$ to related type strains was $21.2-52.6 \%$ (Table 2). These values were far below the value of $70 \%$ recommended by Wayne et al. (1987) for strains of the same species. The DNA G+C content of strain HBUM $20038^{\mathrm{T}}$ is $71.1 \mathrm{~mol} \%$ (determined by HPLC).

In summary, strain HBUM $20038^{\mathrm{T}}$ can be classified in the genus Nocardiopsis based on $16 \mathrm{~S}$ rRNA gene sequence

Table 2. $16 \mathrm{~S}$ rRNA gene sequence similarities and DNADNA relatedness between HBUM $20038^{\top}$ and related type strains of the genus Nocardiopsis

\begin{tabular}{|c|c|c|}
\hline Strain & $\begin{array}{l}16 S \text { rRNA gene } \\
\text { sequence } \\
\text { similarity }(\%)\end{array}$ & $\begin{array}{c}\text { DNA-DNA } \\
\text { relatedness } \\
\quad \%)\end{array}$ \\
\hline HBUM $20038^{\mathrm{T}}$ & $(100)$ & 100 \\
\hline N. prasina DSM $43845^{\mathrm{T}}$ & 99.29 & 52.6 \\
\hline N. metallicus DSM $44598^{\mathrm{T}}$ & 99.29 & 49.9 \\
\hline N. exhalans DSM $44407^{\mathrm{T}}$ & 99.0 & 44.3 \\
\hline N. alba DSM $43377^{\mathrm{T}}$ & 98.64 & 37.2 \\
\hline N. aegyptia DSM $44442^{\mathrm{T}}$ & 98.64 & 33.4 \\
\hline N. lucentensis DSM $44048^{\mathrm{T}}$ & 98.35 & 34.8 \\
\hline N. listeri DSM $40297^{\mathrm{T}}$ & 98.21 & 29.1 \\
\hline N. alkaliphila DSM $44657^{\mathrm{T}}$ & 97.84 & 26.9 \\
\hline N. umidischolae DSM $44362^{\mathrm{T}}$ & 97.84 & 28.5 \\
\hline $\begin{array}{l}\text { N. dassonvillei subsp. albirubida } \\
\text { DSM } 40465^{\mathrm{T}}\end{array}$ & 97.4 & 25.8 \\
\hline $\begin{array}{l}\text { N. synnemataformans DSM } \\
44143^{\mathrm{T}}\end{array}$ & 97.4 & 21.2 \\
\hline
\end{tabular}


similarity and its morphological characteristics, cell-wall chemotype, menaquinone composition, phospholipid type and DNA base composition. The results of physiological tests (Table 1) show that there are clear differences between strain HBUM $20038^{\mathrm{T}}$ and other species of the genus Nocardiopsis. DNA-DNA hybridization is the standard for designation of species (Wayne et al., 1987) and the criterion for membership of the same species is $\geqslant 70 \%$ DNA-DNA relatedness (Wayne et al., 1987). The levels of DNA-DNA relatedness between strain HBUM $20038^{\mathrm{T}}$ and related type strains are $21.2-52.6 \%$ (Table 2 ), which were $<70 \%$. It is therefore proposed that strain HBUM $20038^{\mathrm{T}}$ be classified as the type strain of the novel species Nocardiopsis ganjiahuensis sp. nov.

\section{Description of Nocardiopsis ganjiahuensis sp. nov.}

Nocardiopsis ganjiahuensis (gan.jia.hu.en'sis. N.L. fem. adj. ganjiahuensis pertaining to Ganjiahu Natural Reserve, Xinjiang, north-west China, where the type strain was isolated).

Aerobic and Gram-positive. The surface of colonies is powdery. The colour of the aerial mycelium is grey-white and the substrate mycelium is light-yellowish. The aerial mycelium divides into rod-shaped, irregular-sized spores $(0.3-0.5 \times 1.0-2.0 \mu \mathrm{m})$. Spores are smooth and nonmotile. The substrate mycelium is long, well-developed and branched. No diffusible pigments are produced. Whole-cell hydrolysates contain meso-diaminopimelic acid, but no diagnostic sugars. Polar lipids are diphosphatidylglycerol, phosphatidylcholine and phosphatidylmethylethanolamine. The predominant menaquinones are MK-10 $\left(\mathrm{H}_{2}\right)$ and $\mathrm{MK}-10\left(\mathrm{H}_{4}\right)$; in addition, there are substantial amounts of MK-10 $\left(\mathrm{H}_{6}\right)$. Major cellular fatty acids are iso- $\mathrm{C}_{16: 0}(41.03 \%), \mathrm{C}_{18: 1} \omega 9 c(14.73 \%)$ and tuberculostearic acid (10-methyl $\left.\mathrm{C}_{18: 0}\right)(9.69 \%)$. The $\mathrm{G}+\mathrm{C}$ content of the DNA of the type strain is $71.1 \mathrm{~mol} \%$. Grows occurs at $\mathrm{pH} 8.5-13$, while optimum growth occurs at $\mathrm{pH} 8.5-9.5$. No growth at $\mathrm{pH}$ 7.0. Grows optimally at $28-32{ }^{\circ} \mathrm{C}$; growth occurs at $10{ }^{\circ} \mathrm{C}$, with no growth at $42{ }^{\circ} \mathrm{C}$. Grows well on medium without $\mathrm{NaCl}$ and with 1,3 and $5 \% \mathrm{NaCl}$, but no growth occurs at $10 \%(\mathrm{w} / \mathrm{v})$ $\mathrm{NaCl}$. L-Arabinose, D-xylose, myo-inositol, glycerol and Lrhamnose are utilized as sole carbon sources, but not sucrose, lactose or cellobiose. Positive reactions are found for reduction of nitrate and production of urease. Tween 80 can be degraded, but not Tween 85 .

The type strain is strain HBUM $20038^{\mathrm{T}}\left(=\mathrm{DSM} 45031^{\mathrm{T}}\right.$ $=$ CGMCC $4.3500^{\mathrm{T}}$ ), isolated from soil.

\section{Acknowledgements}

The work was supported by the National Natural Science Foundation of China (3027002), the Foundation of the National Basic Research Program of China (2006CB100206) and the Foundation of the National Program for Basic $S$ and $T$ Platform Construction (2005DKA21201-10).

\section{References}

Collins, M. D. (1985). Analysis of isoprenoid quinones. Methods Microbiol 18, 329-366.

Collins, M. D. \& Jones, D. (1981). Distribution of isoprenoid quinone structural types in bacteria and their taxonomic implication. Microbiol Mol Biol Rev 45, 316-354.

De Ley, J., Cattoir, H. \& Reynaerts, A. (1970). The quantitative measurement of DNA hybridization from renaturation rates. Eur $J$ Biochem 12, 133-142.

Euzéby, J. P. (2007). Nocardiopsis (Brocq-Rousseau 1904) Meyer 1976, genus. In List of Prokaryotic Names with Standing in Nomenclature. Accessed February 2007. http://www.bacterio.cict.fr/ n/nocardiopsis.html

Evtushenko, L. I., Taran, V. V., Akimov, V. N., Kroppenstedt, R. M., Tiedje, J. M. \& Stackebrandt, E. (2000). Nocardiopsis tropica sp. nov., Nocardiopsis trehalosi sp. nov., nom. rev. and Nocardiopsis dassonvillei subsp. albirubida subsp. nov., comb. nov. Int J Syst Evol Microbiol 50, 73-81.

Felsenstein, J. (1981). Evolutionary trees from DNA sequences: a maximum likelihood approach. J Mol Evol 17, 368-376.

Felsenstein, J. (1993). PHYLIP (phylogeny inference package), version 3.5c. Distributed by the author. Department of Genome Sciences, University of Washington, Seattle, USA.

Fitch, W. M. \& Margoliash, E. (1967). Construction of phylogenetic trees. Science 155, 279-284.

Grund, E. \& Kroppenstedt, R. M. (1990). Chemotaxonomy and numerical taxonomy of the genus Nocardiopsis Meyer 1976. Int J Syst Bacteriol 40, 5-11.

Hasegawa, T., Takizawa, M. \& Tanida, S. (1983). A rapid analysis for chemical grouping of aerobic actinomycetes. J Gen Appl Microbiol 29, 319-322.

Holt, J. G., Krieg, N. R. \& Sneath, P. H. A. (editors) (1994). Bergey's Manual of Determinative Bacteriology, 9th edn. Baltimore: Williams \& Wilkins.

Jukes, T. H. \& Cantor, C. R. (1969). Evolution of protein molecules. In Mammalian Protein Metabolism, vol. 3, pp. 21-132. Edited by H. H. Munro. New York: Academic Press.

Komagata, K. \& Suzuki, K. (1987). Lipid and cell-wall analysis in bacterial systematics. Methods Microbiol 19, 161-207.

Kroppenstedt, R. M. (1985). Fatty acid and menaquinone analysis of actinomycetes and related organisms. In Chemical Methods in Bacterial Systematics (Society for Applied Bacteriology Technical Series vol. 20), pp. 173-199. Edited by M. Goodfellow \& D. E. Minnikin. New York: Academic Press.

Kroppenstedt, R. M. (1992). The genus Nocardiopsis. In The Prokaryotes, 2nd edn, pp. 1139-1156. Edited by A. Balows, H. G. Trüper, M. Dworkin, W. Harder \& K. H. Schleifer. New York: Springer.

Kutchma, A. J., Roberts, M. A., Knaebel, D. B. \& Crawford, D. L. (1998). Small-scale isolation of genomic DNA from Streptomyces mycelia or spores. Biotechniques 24, 452-456.

Lane, D. J., Pace, B., Olsen, G. J., Stahl, D. A., Sogin, M. L. \& Pace, N. R. (1985). Rapid determination of $16 \mathrm{~S}$ ribosomal RNA sequences for phylogenetic analyses. Proc Natl Acad Sci U S A 82, 6955-6959.

Lechevalier, M. P. \& Lechevalier, H. A. (1970). Chemical composition as a criterion in the classification of aerobic actinomycetes. Int $J$ Syst Bacteriol 20, 435-443.

Lechevalier, H. A. \& Lechevalier, M. P. (1980). The chemotaxonomy of actinomycetes. In Actinomycete Taxonomy, pp. 227-291. Special 
Publication No. 6. Edited by A. Dietz \& D. Thayer. Arlington, VA: Society for Industrial Microbiology.

Lechevalier, M. P., De Bièvre, C. \& Lechevalier, H. A. (1977). Chemotaxonomy of aerobic actinomycetes: phospholipid composition. Biochem Syst Ecol 5, 249-260.

Marmur, J. (1961). A procedure for the isolation of deoxyribonucleic acid from microorganisms. J Mol Biol 3, 208-218.

Mesbah, M., Premachandran, U. \& Whitman, W. B. (1989). Precise measurement of $\mathrm{G}+\mathrm{C}$ content of deoxyribonucleic acid by highperformance liquid chromatography. Int J Syst Bacteriol 39, 159-167.

Meyer, J. (1976). Nocardiopsis, a new genus of the order Actinomycetales. Int J Syst Bacteriol 26, 487-493.

Peltola, J. S. P., Andersson, M. A., Kämpfer, P., Auling, G., Kroppenstedt, R. M., Busse, H.-J., Salkinoja-Salonen, M. S. \& Rainey, F. A. (2001). Isolation of toxigenic Nocardiopsis strains from indoor environments and description of two new Nocardiopsis species, $N$. exhalans sp. nov. and N. umidischolae sp. nov. Appl Environ Microbiol 67, 4293-4304.

Sabry, S. A., Ghanem, N. B., Abu-Ella, G. A., Schumann, P., Stackebrandt, E. \& Kroppenstedt, R. M. (2004). Nocardiopsis aegyptia sp. nov., isolated from marine sediment. Int J Syst Evol Microbiol 54, 453-456.

Saitou, N. \& Nei, M. (1987). The neighbor-joining method: a new method for reconstructing phylogenetic trees. Mol Biol Evol 4, 406-425.

Sasser, M. (1990). Identification of bacteria by gas chromatography of cellular fatty acids. USFCC Newsl 20, 16.

Schippers, A., Bosecker, K., Willscher, S., Spröer, C., Schumann, P. \& Kroppenstedt, R. M. (2002). Nocardiopsis metallicus sp. nov., a metal-leaching actinomycete isolated from an alkaline slag dump. Int J Syst Evol Microbiol 52, 2291-2295.

Shirling, E. B. \& Gottlieb, D. (1966). Methods for characterization of Streptomyces species. Int J Syst Bacteriol 16, 313-340.

Thompson, J. D., Gibson, T. J., Plewniak, F., Jeanmougin, F. \& Higgins, D. G. (1997). The CLUSTAL_X windows interface: flexible strategies for multiple sequence alignment aided by quality analysis tools. Nucleic Acids Res 25, 4876-4882.

Wayne, L. G., Brenner, D. J., Colwell, R. R., Grimont, P. A. D., Kandler, O., Krichevsky, M. I., Moore, L. H., Moore, W. E. C., Murray, R. G. E. \& other authors (1987). International Committee on Systematic Bacteriology. Report of the ad hoc committee on reconciliation of approaches to bacterial systematics. Int J Syst Bacteriol 37, 463-464. 